\title{
HUMAN RESOURCE MANAGEMENT IN PROJECT MANAGEMENT: IDEAS AT THE CUSP
}

\author{
Dr Ravikiran Dwivedula \\ Department of Business Administration, Faculty of Arts, \\ Brandon University, Manitoba, Canada
}

\begin{abstract}
Human resource management is an important function when managing projects. Over the years, project management has developed and consolidated a robust theory base that lead to a body of knowledge that is unique to its practice and distinct within the larger management discipline. In this direction, this is an opportune moment to reflect on the themes explored within the project management literature that is specific to managing people. Using 104 peer-reviewed articles extracted from web of science database, 6 research themes have been identified that lie at the intersection of project management and human resource management. Co-occurrence of key words is the methodology employed. The themes are Human resource management as a critical success factor for projects, Project manager as an enabler of project success, Projects human resource as vehicle for organizational competitiveness, Project-Human Resource management as engines of innovation, People management competencies of project manager, and Contextual competencies of project manager.
\end{abstract}

Key words: co-occurrence of key words, human resource management, project management, qualitative research.

\section{INTRODUCTION}

Human resource management is defined as management of systems, policies, and practices related to people in order to achieve personal and organizational goals. Given the technological, social, and economic influences on the organizations, human resource management is evolving to a strategically important function (Josler, \& Burger, 2005). On the other hand, project management has emerged as a strong discipline with a strong body of knowledge that includes distinct theory and practice (Wessels, 2007). Therefore, the convergence of these two constantly evolving domains of management is a fertile ground to explore novel ideas with importance to theory and practice.

Managing people in projects is essential for project success and is of strategic importance to the organization. Projects are temporary and unique in nature. Given the specific resource requirements of each project, the human resource configuration- policies, systems, and practices, will change according to the project (Huemann, Turner, \& Keegan, 2004). The increasing demand for qualified project workers further increases the importance of human resource management to projects, and project management (Ekrot, Rank, Kock, \& Gemunden, 2018). While people management on projects has been of significant interest to project practitioners, only recently have academics turned their focus to a rigorous study of human resource practices specific to projects. The current paper reviewes these research studies.

The motivation for this current research stems from the question - what is the status of literature at the crossroads of human resource management and project management?

Thus, the objective of this paper is to :

- Identify the research themes common to project management and human resource management domains.

The organization of the paper is as follows. First, the overarching literature review that points to research themes pertinent to managing people on projects is presented. Second, is the methodology section where the 
qualitative research method - 'co-occurrence of key words' used to analyze the theoretical corpus in this study is explained in detail. Third, the research themes, and the key words within those research themes are summarized. Fourth, a discussion of the six research themes that lie at the intersection of human resource management and project management studies is presented. This is followed by the conclusion.

\section{LITERATURE REVIEW}

There is an increasing interest in the study of human resource management variables within project management. The research studies are within the general domain of management followed by peer-reviewed articles from industrial engineering, civil engineering, electrical and electronic engineering, and computer science \& applications. Furthermore, the research is equally represented in traditional journals from both the domains (such as international journal of project management, and international journal of human resource management). Such a trend indicates cross-fertilization of ideas between these two disciplines.

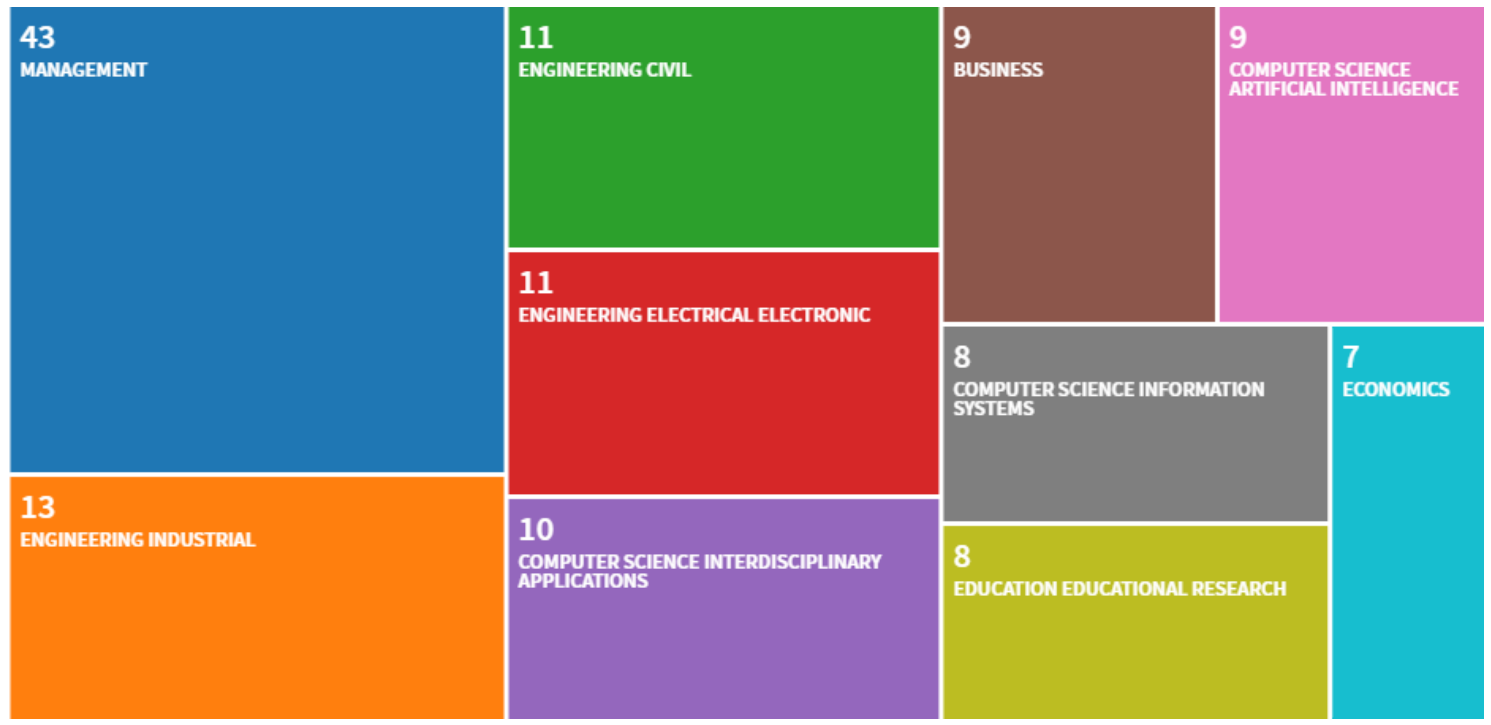

Figure 1: Research areas
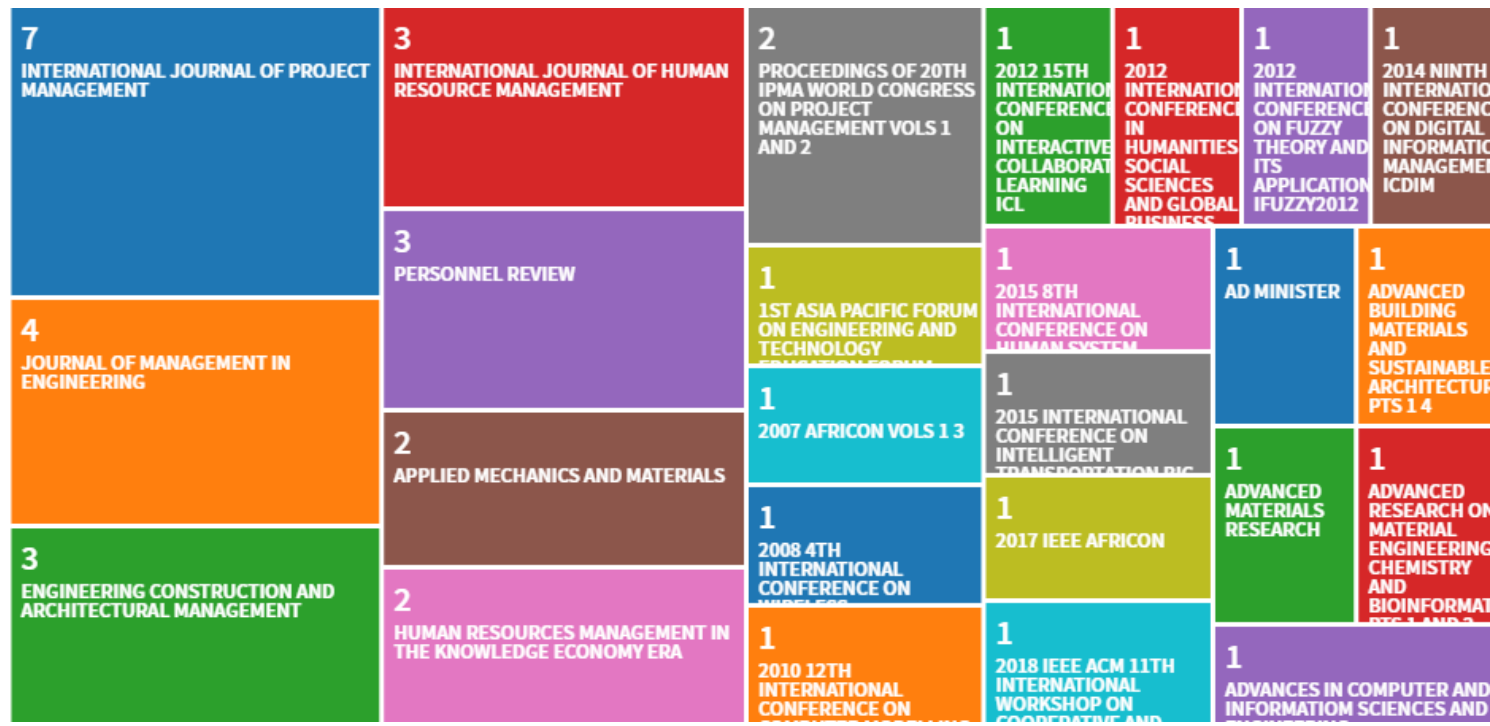

Figure 2: Research Journals \& Conferences

Extant literature brought to the fore important themes that lie at the intersection of these two management domains (c.f. Keegan, Ringhofer, \& Huemann, 2018; Dociu, 2018; Pak, Carden, 
\& Kovach, 2016; Ling, Ning, Chang, \& Zhang, 2018). Themes such as human resource practices to manage project teams (Dociu, 2018), human resource management theory as reflected in major project management journals (Keegan et al., 2018), new project worker socializing and orientation (Batistič, \& Kenda, 2018), and the effect of perceived organizational support on the turnover intent of project managers (Ekrot et al., 2018). While the research on managing people on projects has increased over the years, systematic reviews that summarize the research themes which set the direction for further research may have been wanting. This paper attempts to address this research gap.

\section{METHODOLOGY}

In order to identify the underlying research themes, the frequency trend analysis of the key terms was followed by the construction of a social graph. VosViewer 1.6.10 (created by Lieden University Center for Science and Technology; also see van Eck, \& Waltman, 2017 for a more detail explanation of the tool), an open source data analysis and visualization tool was used. The tool organizes the terms into various clusters which are color-coded. The words are counted for their presence in the documents using binary counting method, i.e., the number of times one word appears with another word. This counting of such cooccurring words is run iteratively until the words with proximity (words pairs appearing together) are grouped in a cluster. Figure 3 is a graphical representation of the association between the key words extracted using cooccurrence technique.

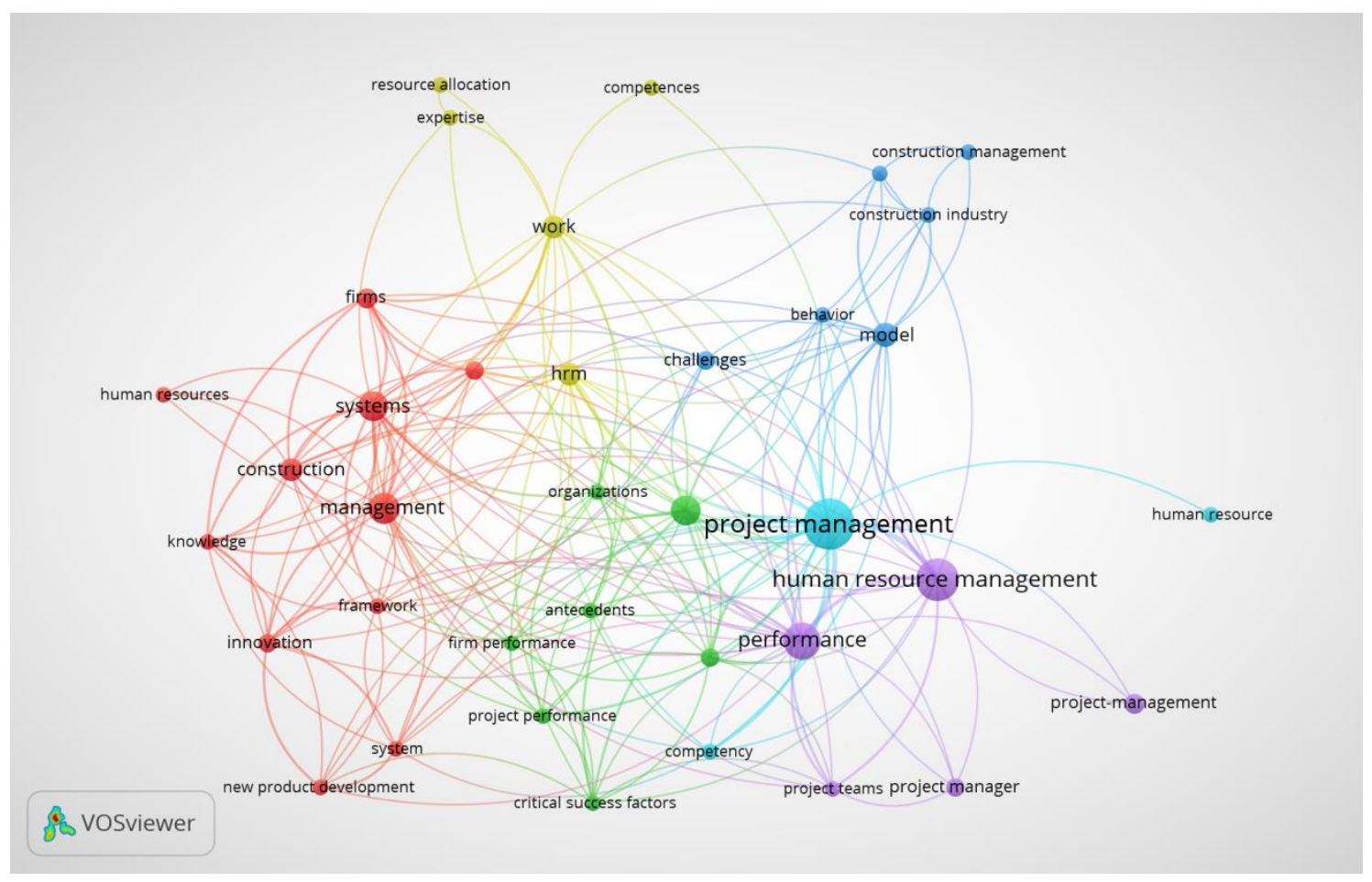

Figure 3: Social graph: co-occurrence of key word analysis

\section{FINDINGS}

The co-occurrence of key word analysis of 104

The themes are summarized in Table 1 below. peer-reviewed articles reveal six major themes. 
Table 1: Research themes extracted from co-occurrence of key word analysis

\begin{tabular}{|l|l|}
\hline Cluster & Key words \\
\hline Cluster 1 & $\begin{array}{l}\text { Antecedents, critical success factors, firm performance, human resource management, } \\
\text { organizations, product development, project performance }\end{array}$ \\
\hline Cluster 2 & $\begin{array}{l}\text { Behavior, challenges, construction industry, construction management, model, } \\
\text { project managers }\end{array}$ \\
\hline Cluster 3 & $\begin{array}{l}\text { Competitive advantage, construction, firms, framework, human resources, } \\
\text { innovation, knowledge management, new product development, systems }\end{array}$ \\
\hline Cluster 4 & Framework, innovation, knowledge management, new product development, system \\
\hline Cluster 5 & $\begin{array}{l}\text { Human resource management, performance, project manager, project teams, project } \\
\text { manager }\end{array}$ \\
\hline Cluster 6 & Competencies, expertise, human resource management, resource allocation, work \\
\hline
\end{tabular}

\section{DISCUSSION}

The co-occurrence of key word reveals six major research themes that lie at the intersection of human resource management, and project management research. These themes pertain to the significance of projecthuman resource management practices for project success, and for organization's performance. Extant research also focuses on the competencies of the project manager. These themes are discussed in detail in this section.

\section{Cluster 1. Human resource management as a critical success factor for projects}

Human resource practices such as team development have been found to be moderate predictors of project performance. This relationship however is moderated by the project duration where projects with longer duration have been found to increase the effect of team development practices on success (Zwikael, \& Unger-Aviram, 2010). Other research is more vocal about the impact of human resource practices. Demirkesen, and Ozorhon (2017) suggest human resource management to be important over project scope, and time management in determining project performance. In the same direction, empowering project team members is seen as an important aspect of people management in delivering successful projects (Dayan, \& Basarir, 2010; Pons, 2008). Therefore, people management has important implications for project management in terms of successful project delivery.

\section{Cluster 2. Project manager as an enabler of project success}

Project manager is the executor of the organization's strategy through the project. Therefore, this role plays a paramount role in completing the projects efficiently (An, Qiang, Wen, Jiang, \& Xia, 2019). Managing the project manager's behavior thus assumes significance. Extant research points to factors such as skill discretion, decision authority, job demands, job security, job readjustment, and family support as being important to reduce project manager's stress during the project execution (An et al, 2019). Extending this line of argument, Ekrot et al., (2018) apply the construct of perceived organizational support (POS) to project-based organizations. Their study underscores the importance of organizations' support in terms of career development, and project portfolio management (allocating adequate resources to the project) to project manager's job satisfaction.

\section{Cluster 3: Projects human resource as vehicle for organizational competitiveness}

In his 1988 article, Archibald first described projects as vehicles for organization's strategic growth. He describes how organizations that adopt a growth strategy, use programs, and projects to improve their products, services, markets, systems, procedures, and people. These findings maintain their relevance after three decades. Managerial support has a significant effect on the human resource practices in project types such as new product development. 
Senior management's proclivity for taking risks, managing conflicts, and knowledge management has an impact on the firm's human resource practices and further on the performance (Roy, Dan, \& Modak, 2018). In a similar vein, research findings also indicate that the firm's human resource practices are a determinant of a project manager's satisfaction with one's job. This has implications for the project's overall performance (Ling et al., 2018). Thus, research is unequivocal in stating the importance of human resource management, senior management's strategy, and knowledge management as being important for firm's competitive advantage, more so for project-based organizations (Loufrani-Fedida, \& Saglietto, 2016).

\section{Cluster 4. Project-Human Resource management as engines of innovation}

The success of an enterprise depends on the development and implementation of innovative ideas. Projects when linked to the organization's strategy act as engines of innovation. Traditional human resource practices may not advance this goal. Managing technology, people, and project specificities have to be considered holistically to this end (Apenko, 2017). In order to develop such a holistic system of technology-people-projects, organizations will need to cultivate a culture of knowledge sharing and collaboration among the project workers. While exchange of explicit (documented) knowledge has long been established to be important for the functioning of projects, sharing of tacit knowledge (which resides in the experience and memory of project workers) is more challenging and is the focus of numerous research studies (Olaniran, 2017; Terhorst, Lusher, Bolton, Elsum, \& Wang, 2018; Wioleta, 2017). Sharing of tacit knowledge is a key factor to foster trust and creativity in project teams. Thus, a collaborative culture (Kucharska, \& Kowalczyk, 2016), and human resource practices (Popaitoon, \& Siengthai, 2014) are instrumental in driving the organization's innovation through projects.

\section{Cluster 5. People management competencies of project manager}

Extant research has also called for expanding the scope of project manager's competency to areas outside project management, to especially human resource management, as projects become more complex (Reusch, Khushnood, \& Kaufmann, 2011). The project manager's competencies broadly fall into three areas- knowledge of project management processes, managing project performance, and managing people (Sebt, Shahhosseini, \& Rezaei, 2010). These models for project manager's competency are grounded in previous studies that underscored team leadership, emotional intelligence (Dainty, Cheng, \& Moore, 2005), teamwork, problem solving, engagement \& motivation, openness, and creativity (Shahhosseini, \& Sebt, 2011). Interestingly, research clearly delineates the project manager's human resource competencies from technical (for example managing project scope, and time, contract management), and contextual competencies (for example technology management, program-portfolio management, and adapting to business environment, Shahhosseini, \& Sebt, 2011).

\section{Cluster 6. Contextual competencies of project manager}

Assigning human resources to projects is contingent on the characteristics of a project. A temporary endeavor with specific objectives to be achieved, traditional human resource practices may fall short in meeting the project objectives. In cases where the temporary project organization is situated within the larger permanent organization, development of objective key performance indicators for each project derived from the organization's objectives will ensure effective utilization of project resources (Hao, \& $\mathrm{Li}, 2010)$. With emerging approaches such as agile project management, self-organizing teams with greater levels of autonomy are becoming a common place. Such teams share the project management activities such as estimation, planning, and requirement analysis with the managers and the customers. Challenges such as lack of senior management support, failure to define dependencies when scheduling tasks, ambiguous acceptance criteria for project deliverables will mar the project performance (Hoda, \& Murugesan, 2016). Therefore modern project manager needs to demonstrate contextual competencies related to crossorganizational project governance (when the 
project is shared by multiple organizational units or between multiple organizations, Sommer, Dukovska-Popovska, \& StegerJensen, 2014), and emergent management approaches such as design thinking, agile management, and business analytics (Claus, 2019).

\section{CONCLUSION}

In this paper, publishing trends that lie at the cusp of two dynamic domains of managementproject management, and human resource management are reported. Through an extensive and systematic analysis, six major themes are identified. These themes underscore the importance of project-human resource practices to organization performance and growth. Project manager's competencies also emerged as a dominant research theme. While this paper identifies a few of these promising areas for research, there are other opportunities to enrich our understanding of both these disciplines. Technology trends such as artificial intelligence and big data are redefining the human resource management practices such as HR planning (Moyo, Doan, Yun, \& Tshuma, 2018) employee hiring (c.f. Cohen, 2019; Rodney, Valaskova, \& Durana, 2019), performance management (Buck, \& Morrow, 2018), and training (Sniezek, Wilkins, Wadlington, \& Baumann, 2002; Bassi, \& McMurrer, 2016). The impact of technology on project management processes is equally profound (Wauters, \& Vanhoucke, 2016). Processes such as project control (Ko, \& Cheng, 2007), cost management (Zervos, Oliveira, \& Duckworth, 2018), contract management (Chou, Hsu, Lin, \& Chang, 2016), and risk management (Haji Karimian, Mbachu, Egbelakin, \& Shahzad, 2019). Other areas of interest could be employee engagement (Batistič, \& Kenda, 2018), and motivation (Havermans, Van der Heijden, Savelsbergh, \& Storm, 2019) with implications for project resource management. As projects become more complex, and employee expectations become more diverse, there needs to be an ongoing dialog to address these issues. It is expected that this paper will become a point of departure for this dialog.

\section{REFERENCES}

An, N., Qiang, M., Wen, Q., Jiang, H., \& Xia, B. (2019). Contribution of project managers' capability to project ending performance under stressful conditions. European Management Journal, 37(2), 198-209.

Apenko, S. (2017). Human resource management of innovative projects in the context of business strategy. Strategic Management, 22(1), 3-6.

Archibald, R. D. (1988). Projects: vehicles for strategic growth. Project Management Journal, 19(4), 31-34.

Bassi, L., \& McMurrer, D. (2016). Four lessons learned in how to use human resource analytics to improve the effectiveness of leadership development. Journal of Leadership Studies, 10(2), 39-43. https://doi.org/10.1002/jls.21471

Batistič, S., \& Kenda, R. (2018). Toward a model of socializing project team members: An integrative approach. International Journal of Project Management, 36(5), 687-700. https://doiorg.berlioz.brandonu.ca/10.1016/j.ijprom an.2018.03.003

Buck, B., \& Morrow, J. (2018). AI, performance management and engagement: keeping your best their best. Strategic HR Review, 17(5), 261-262.

Chou, J.-S., Hsu, S.-C., Lin, C.-W., \& Chang, Y.-C. (2016). Classifying Influential Information to Discover Rule Sets for Project Disputes and Possible Resolutions. International Journal of Project Management, 34(8), 1706-1716. https://doi.org/10.1016/j.ijproman.2016.1 0.001

Claus, L. (2019). HR disruption-Time already to reinvent talent management. $B R Q$ Business Research Quarterly, 22(3), 207-215.

Cohen, T. (2019). How to leverage artificial intelligence to meet your diversity goals. Strategic HR Review, 18(2), 62-65.

Dainty, A. R., Cheng, M. I., \& Moore, D. R. (2005). Competency-based model for predicting construction project managers' performance. Journal of Management in Engineering, 21(1), 2-9. 
Dayan, M., \& Basarir, A. (2010). Antecedents and consequences of team reflexivity in new product development projects. Journal of Business \& Industrial Marketing, 25(1), 18-25.

Demirkesen, S., \& Ozorhon, B. (2017). Measuring project management performance: Case of construction industry. Engineering Management Journal, 29(4), 258-277.

Dociu, A. M. M. (2018). The Importance of Human Resources in Project Management. Knowledge Horizons / Orizonturi Ale Cunoasterii, 10(3), 8-14

Ekrot, B., Rank, J., Kock, A., \& Gemünden, H. G. (2018). Retaining and satisfying project managers-antecedents and outcomes of project managers' perceived organizational support. The International Journal of Human Resource Management, 29(12), 1950-1971.

Haji Karimian, S., Mbachu, J., Egbelakin, T., \& Shahzad, W. (2019). Improving efficiency in roading projects: a New Zealand study. Engineering Construction \& Architectural Management (09699988), 26(5), 827-849. https://doi.org/10.1108/ECAM-02-20180060

Hao, D., \& Li, X. (2010). Research on human resource management of project-oriented enterprises. In the Proceedings of 3rd International Forum of Human Resource Strategy and Development, Jianan City, Chia

Havermans, L., Van der Heijden, B. I. J. M., Savelsbergh, C., \& Storm, P. (2019). Rolling Into the Profession: Exploring the Motivation and Experience of Becoming a Project Manager. Project Management Journal, 50(3), 346-360. https://doi.org/10.1177/87569728198327 82

Hoda, R., \& Murugesan, L. K. (2016). Multilevel agile project management challenges: A self-organizing team perspective. The Journal of Systems \& Software, 117, 245-257.

Huemann, M., Turner, R., \& Keegan, A. (2004). Managing human resources in the project- oriented company. The Wiley guide to managing projects, 1061-1086.

Josler, C., \& Burger, J. (2005). Project Management Methodology in Human
Resource Management. CUPA-HR Journal, 56(2), 25-30.

Keegan, A., Ringhofer, C., \& Huemann, M. (2018). Human resource management and project based organizing: Fertile ground, missed opportunities and prospects for closer connections. International Journal of Project Management, 36(1), 121-133. https://doi-

org.berlioz.brandonu.ca/10.1016/j.ijprom an.2017.06.003)

Ko, C.-H., \& Cheng, M.-Y. (2007). Dynamic Prediction of Project Success Using Artificial Intelligence. Journal of Construction Engineering \& Management, 133(4), 316-321. https://doi.org/10.1061/(ASCE)07339364(2007)133:4(316)

Kucharska, W., \& Kowalczyk, R. (2016). Trust, collaborative culture, and tacit knowledge sharing in project management: A relationship model. Proceedings of 13th International Conference on Intellectual Capital Knowledge Management and Organizational Learning (ICICKM), Ithaca, NY, USA, Oct 14-15, 2016.

Ling, F. Y. Y., Ning, Y., Chang, Y. H., \& Zhang, Z. (2018). Human resource management practices to improve project managers' job satisfaction. Engineering, Construction and Architectural Management, 25(5), 654-669.

Loufrani-Fedida, S., \& Saglietto, L. (2016). Mechanisms for managing competencies in project-based organizations: An integrative multilevel analysis. Long Range Planning, 49(1), 72-89.

Moyo, S., Doan, T. N., Yun, J. A., \& Tshuma, N. (2018). Application of machine learning models in predicting length of stay among healthcare workers in underserved communities in South Africa. Human Resources for Health, 16(1), N.PAG. https://doi.org/10.1186/s12960-0180329-1

Olaniran, O. (2017). Barriers to Tacit Knowledge Sharing in Geographically Dispersed Project Teams in Oil and Gas Projects. Project

Management Journal, 48(3), 41-57.

Pak, A., Carden, L. L., \& Kovach, J. V. (2016). Integration of project management, 
human resource development, and business teams: A partnership, planning model for organizational training and development initiatives. Human Resource Development International, 19(3), 245260. https://doiorg.berlioz.brandonu.ca/10.1080/136788 $\underline{68.2016 .1141606}$

Pons, D. (2008). Project management for new product development. Project management journal, 39(2), 82-97.

Popaitoon, S., \& Siengthai, S. (2014). The moderating effect of human resource management practices on the relationship between knowledge absorptive capacity and project performance in projectoriented companies. International Journal of Project Management, 32(6), 908-920.

Reusch, P., Khushnood, M., \& Kaufmann, S. V. (2011, September). Concepts on competences in project management. In Proceedings of the 6th IEEE International Conference on Intelligent Data Acquisition and Advanced Computing Systems, 2, 884-889.

Rodney, H., Valaskova, K., \& Durana, P. (2019). The Artificial Intelligence Recruitment Process: How Technological Advancements Have Reshaped Job Application and Selection Practices. Psychosociological Issues in Human Resource Management, 7(1), 4247.

Roy, S., Dan, P. K., \& Modak, N. (2018). Cascading effects of management actions on NPD in the manufacturing sector: The Indian context. Journal of Manufacturing Technology Management,29(7), 11151137.

Sebt, M. H., Shahhosseini, V., \& Rezaei, M. (2010). Competency based optimized assignment of project managers to projects. In 2010 12th International Conference on Computer Modelling and Simulation, 311-316, IEEE.

Shahhosseini, V., \& Sebt, M. H. (2011). Competency-based selection and assignment of human resources to construction projects. Scientia Iranica, 18(2), 163-180.

Sniezek, J. A., Wilkins, D. C., Wadlington, P. L., \& Baumann, M. R. (2002). Training for crisis decision-making: Psychological issues and computer-based solutions. Journal of Management Information Systems, 18(4), 147-168.

Sommer, A. F., Dukovska-Popovska, I., \& Steger-Jensen, K. (2014). Barriers towards integrated product development-Challenges from a holistic project management perspective. International Journal of Project Management, 32(6), 970-982.

Terhorst, A., Lusher, D., Bolton, D., Elsum, I., \& Wang, P. (2018). Tacit Knowledge Sharing in Open Innovation Projects. Project Management Journal, 49(4), 5-19.

Wauters, M., \& Vanhoucke, M. (2016). A comparative study of Artificial Intelligence methods for project duration forecasting. Expert Systems with Applications, 46, 249-261. https://doi.org/10.1016/j.eswa.2015.10.00 8

Wessels, D. J. (2007). The emergence of strategic project management. Paper presented at PMI ${ }^{\circledR}$ Global Congress 2007-North America, Atlanta, GA. Newtown Square, PA: Project Management Institute

Wioleta, K. (2017). Relationships between Trust and Collaborative Culture in The Context of Tacit Knowledge Sharing. Journal of Entrepreneurship, Management and Innovation, 13(4), 61-7

Zervos, M., Oliveira, C., \& Duckworth, K. (2018). An investment model with switching costs and the option to abandon. Mathematical Methods of Operations Research,88(3), 417-443. https://doi.org/10.1007/s00186-0180641-5

Zwikael, O., \& Unger-Aviram, E. (2010). HRM in project groups: The effect of project duration on team development effectiveness. International Journal of Project Management, 28(5), 413-421. 